\title{
Um Planejamento composicional a partir de elementos do frevo de rua pernambucano
}

\author{
A Compositional Planning based on Elements of the Street Frevo of Pernambuco
}

\author{
Flávio Lima \\ Instituto Federal de Pernambuco, campus Recife, Recife, Pernambuco, Brasil \\ flaviolima@recife.ifpe.edu.br
}

\section{José Orlando Alves}

Universidade Federal da Paraíba, João Pessoa, Paraíba, Brasil

jorlandoalves2006@gmail.com

\begin{abstract}
Resumo: Este artigo propõe a aplicação de aspectos da Teoria dos Contornos (MORRIS, 1987) na redução melódica de um frevo de rua pernambucano, nas ordenações de classes de alturas, na diversidade tímbrica proposta, e o estabelecimento de elementos musicais (gestos horizontais, forma, número de compassos, partes) na composição de um quinteto para metais. Os eventos rítmicos foram determinados através da elaboração de uma listagem das ocorrências em frevo autoral, mas também em outras cinco de um autor pernambucano, Inaldo Moreira. Com o auxílio de uma das Proporções Revisionárias de Joseph Straus (STRAUS, 1991), a marginalização, esses eventos rítmicos são dispostos de acordo com a frequência de aparecimento nos frevos analisados. Por fim, utilizamos a batida rítmica da célula do frevo para que desempenhe o elo entre a linguagem contemporânea e o frevo de rua. Concluímos que tais metodologias forneceram subsídios necessários para um procedimento compositivo.
\end{abstract}

Palavras-chave: planejamento composicional; Teoria do Contorno; ordenação das alturas; frevo de rua.

Abstract: The purpose of this article is to apply some features of the theory of contour, by Morris (1987), on the melodic reduction of a so-called street frevo, which is a musical genre from Pernambuco, Brazil. It also considers its pitch class order, timbric diversity, and other musical elements, such as horizontal gestures, form, number of bars, and sections. All these features are applied on a piece composed for a brass quintet. The rhythmic events are identified by a list of elements observed in a song composed by the first author of this article and also in other five songs by Inaldo Moreira, a Brazilian composer. Based on Joseph Straus's revisionary ratios (STRAUS, 1990), known as marginalization, such rhyth mic cells are disposed according to how often they appear in the analyzed songs. Finally, the rhythmic tapping is used so that the link between contemporary language and street frevo takes place. It concludes that such methodology provides enough support for a composing process.

Keywords: Compositional Planning; Contour Theory; Pitch Order; Brazilian street frevo.

Submission date: 20 December 2017

Final approval date: 11 June 2018 


\section{1 - Introdução}

O planejamento composicional da peça atonal Criação $n^{\circ} 3$ para quinteto de metais (dois trompetes, trompa, trombone e tuba) foi construído a partir de recursos advindos de frevos de rua pernambucanos obtidos: a) com o estabelecimento de um contorno ${ }^{1}$, a partir da redução da melodia dos cinco primeiros compassos de Nuneziando, frevo de rua composto por Flávio Lima (Figura 1), orquestrado para um grupo convencional do gênero musical, comum nos carnavais pernambucanos: dois saxofones alto, dois saxofones tenor, um saxofone barítono, quatro trompetes e quatro trombones; b) com os eventos rítmicos extraídos do trecho apresentado na mesma figura e do início de cinco outros frevos de rua com mesma orquestração; c) com o timbre, a forma e a fórmula de compasso definidos com o auxílio do contorno obtido no item a).

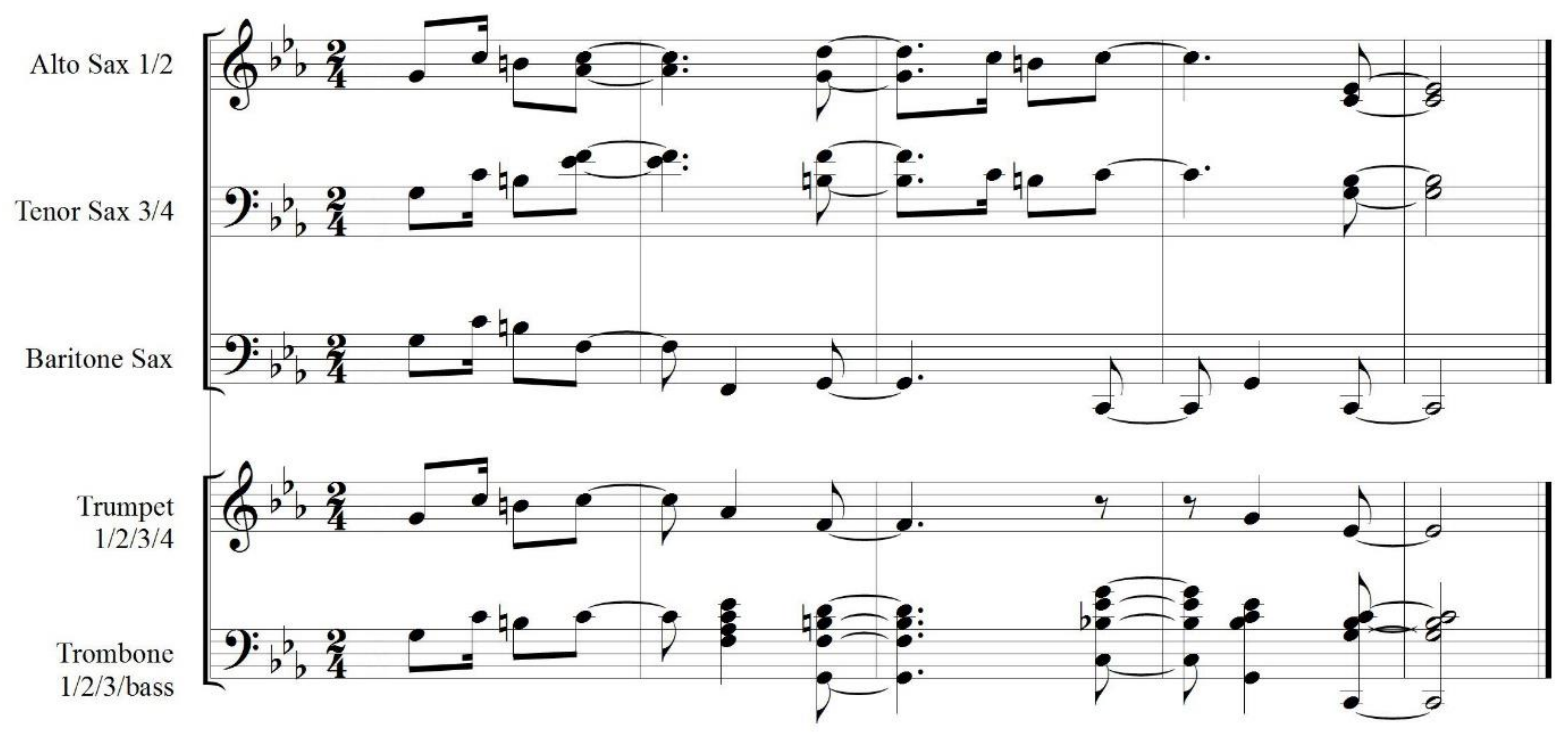

Figura 1: Orquestração de cinco compassos do frevo Nuneziando, com orquestra de sopros.

0 frevo de rua Nuneziando inicia com uma anacruse durando o equivalente a uma semínima duplamente pontuada. Segundo OLIVEIRA (1971, p. 49), “a primeira parte do frevo [que] chamam [de] 'introdução' [...] já é a própria música” e, em seguida, afirma que a "introdução do frevo [...] inicia inalteravelmente por anacruse", tipificando o início dos frevos de rua como surgindo "de forma precipitada". As anacruses variam de frevo para frevo, entretanto, alguns raros frevos de rua não a possuem, e sim, um compasso inicial inteiro, deixando com isso de ser uma anacruse. Exemplificando, 400 anos de Glória, de Severino Araújo, tem uma anacruse ritmicamente igual à do frevo autoral: colcheia, semicolcheia e duas colcheias; 1080, de José Constantino: uma semicolcheia, colcheia, duas semicolcheias, colcheia e semicolcheia (um compasso inteiro); Adriana, de Dimas Sedícias: semicolcheia, pausa de semicolcheia e semicolcheia; Arrepiado, de Nilton e Fernando Rangel: três colcheias; Azeitem as molas, de Gennaldo Medeiros: três semicolcheias; Bico Doce, de José Menezes: colcheia prolongada a uma semicolcheia

1 Contorno é um conjunto ordenado de n alturas aistintas, com ou sem repetições, numerado (não necessariamente de forma adjacente), em ascenção de x a y $(x<y)$ e podem ser escritas como uma sucessão de inteiros ou como um gráfico (MORRIS, 1993, p.206, tradução nossa) 
seguida de três semicolcheias (fonte: arquivos de partituras de Frevos de Rua da Casa do Carnaval, Rua São Pedro, 38, Bairro de São José, Recife - PE); e vários outros exemplos encontrados em arquivos particulares ou públicos com partituras do gênero.

As últimas colcheias de cada compasso da melodia mostrada nas Figuras 1 e 2 são antecipações do compasso subsequente, evento muito comum na música popular. No caso do frevo, samba, baião, xaxado, etc., a referida antecipação rítmica denomina-se "sincopada brasileira" e esse tipo de tipo de divisão é "inerente a este gênero de música" (GUEST, 1996, p.44). PEASE (2001, p.17-18) amp1lia esse tipo de escritura, quando estabelece que a antecipação (anticipation) significa uma nota atacada metade de um tempo antes de um tempo forte e o ataque atrasado (delayed attack), uma nota executada metade de um tempo após um tempo forte. Em ambos os casos, GUEST (1996, p.44), menciona também que esses deslocamentos envolvem não só a nota da melodia, como também a harmonia associada a ela. A Figura 2 apresenta a melodia do frevo da Figura 1 com a cifra popular entre parêntesis e acima do pentagrama, enquanto que abaixo deste a harmonia em cifra funcional é mostrada.

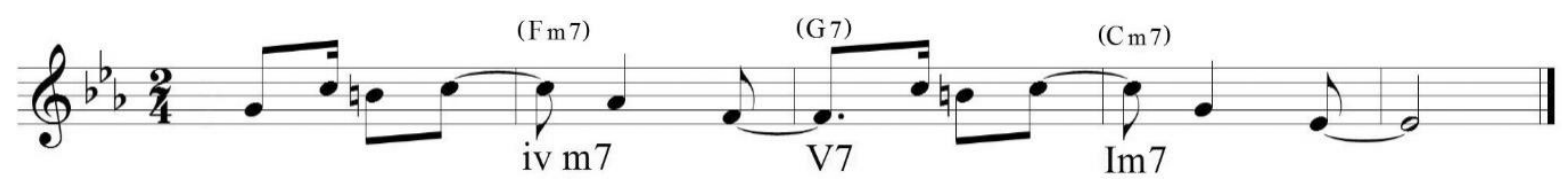

Figura 2: A melodia existente no frevo orquestrado e reproduzido na Figura 1, com a progressão harmônica na cifra popular e na cifra funcional.

Transcrita a melodia do frevo, um tratamento analítico a reduziu a uma sequência de alturas mais importantes (Figura 3), objeto de nosso interesse, possibilitando numerá-las de acordo com o princípio da Teoria dos Contornos e mostrando esses resultados em um gráfico (Figura 4). Outro conceito de Contorno Musical é estabelecido por MORRIS (1993, p.205, tradução nossa), como "um dos aspectos mais gerais da percepção de alturas, anterior ao conceito de pitch ou pitch class, pois é fundamentado apenas à habilidade do ouvinte em ouvir alturas como relativamente mais agudas, iguais ou mais graves, sem que se identifique a exata diferença entre elas". O contorno que obtivemos forneceu possibilidades várias de geração de sequências de alturas, ou seja, os gestos horizontais necessários para a composição, como explicaremos adiante.

Desconsideramos as antecipações e os retardos observados na Figura 1 na redução visando a obtenção do contorno melódico. A primeira nota do frevo, o Sol3, tem uma função denominada por FRAGA (2011, p.55), de "ascensão inicial" e o autor estabelece que essa denominação é atribuída a um "movimento ascendente [...] que parte de uma nota [...] em direção à primeira nota da linha fundamental". Nessa perspectiva analítica, o Sol3 inicial faz um salto para o Dó4 e ambas as alturas têm importância equivalente na redução. A sequência de alturas foi obtida empregando o mesmo entendimento, e não só passou a expressar o contorno da melodia reduzida do frevo, mas também revelou uma numeração: <3 54253 1>, conforme definido por MORRIS (1987, p.27, 283; 1993, p.206). A Figura 3 apresenta a melodia do frevo com apenas as alturas principais e a sequência numérica que revela o contorno. 


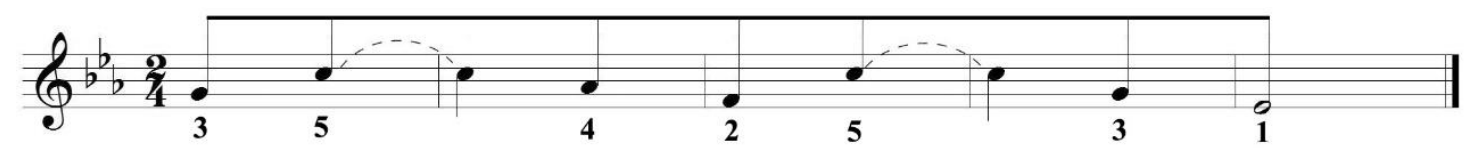

Figura 3: Melodia reduzida do frevo e sequência numérica correspondente ao contorno (<3542531>).

No contorno obtido, <3 54253 1>, o cardinal 1 indica a altura mais grave e o cardinal 5, a mais aguda (MORRIS, 1987, p.27, 283; 1993, p.206). São as sete alturas ordenadas e mostradas na Figura 3 - o contorno - que formaram a unidade melódica básica da composição para quinteto de metais. Esse contorno foi utilizado na composição não só de forma integral, como também segmentado e, em algumas ocasiões, de forma cíclica onde, após atingir a última altura, volta-se a utilizar a primeira. 0 ordenamento, no entanto, foi sempre obedecido, submetendo-se ao contorno original. 0 gráfico deste contorno, segundo o princípio explícito em MORRIS (1987, p.27), é demonstrado na Figura 4:

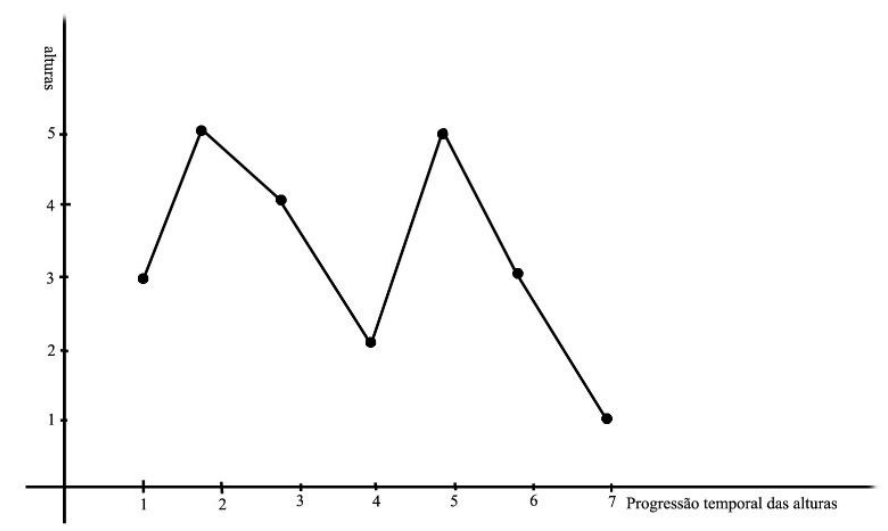

Figura 4: Gráfico dos contornos obtidos na melodia do frevo.

Com base no contorno obtido, construímos a Figura 5 com as respectivas alturas para a construção dos gestos horizontais. A primeira linha dessa tabela define uma sequência com o contorno <3 542531 s, no entanto, com alturas diferentes das mostradas na Figura 3. Isso ocorre porque desejamos um máximo distanciamento tonal possível, fato praticamente impossível com as alturas do contorno original do frevo, já que retratam arpejos de tríades tonais. As demais linhas da Figura 5 são transposições da primeira, de tal maneira que a segunda linha é a anterior meio tom abaixo, a terceira linha, meio tom abaixo da segunda e assim por diante. Os gestos verticais tornaram-se consequência do resultado sonoro da construção dos gestos horizontais, pois o presente planejamento não prevê formalmente tais elaborações verticais. 
LIMA, Flávio; ALVES, José Orlando. (2018) Um Planejamento composicional a partir de elementos do frevo de rua pernambucano. Per Musi. Belo Horizonte: UFMG. p.1-24.

\begin{tabular}{|c|c|}
\hline ordenamento A’ & $\mathrm{f}^{\sharp}-\mathrm{b} b-\mathrm{ab}-\mathrm{f}-\mathrm{b} b-\mathrm{f} \sharp-\mathrm{e}$ \\
\hline ordenamento B' & $\mathrm{f}-\mathrm{a}-\mathrm{g}-\mathrm{e}-\mathrm{a}-\mathrm{f}-\mathrm{e} b$ \\
\hline ordenamento $\mathrm{C}^{\prime}$ & $\mathrm{e}-\mathrm{a} b-\mathrm{gb}-\mathrm{e} b-\mathrm{a} b-\mathrm{e}-\mathrm{d}$ \\
\hline ordenamento $\mathrm{D}^{\prime}$ & $\mathrm{e} b-\mathrm{g}-\mathrm{f}-\mathrm{d}-\mathrm{g}-\mathrm{e} b-\mathrm{d} b$ \\
\hline ordenamento E' & $\mathrm{d}-\mathrm{gb}-\mathrm{e}-\mathrm{d} b-\mathrm{gb}-\mathrm{d}-\mathrm{c}$ \\
\hline
\end{tabular}

Figura 5: Tabela de cinco ordenamentos de alturas que possuem o contorno $<3542531>$.

Formulamos gestos horizontais sem a obrigatoriedade de iniciar a sequência de alturas conforme a Figura 5, ou seja, em diversas ocasiões iniciamos uma sucessão a partir de outras alturas do contorno. No entanto, a continuidade melódica sempre obedeceu ao ordenamento estabelecido. Além disso, ao empregar a última altura do ordenamento, quando necessitávamos dar continuidade ao trecho retornávamos à primeira, visto que 0 contorno é limitado a sete alturas e, por vezes, este quantitativo tornava-se insuficiente. Também admitimos repetições adjacentes de uma mesma altura, pois esse procedimento não compromete o conceito básico da Teoria dos Contornos, segundo MORRIS (1993, p.206) $)^{2}$.

\section{2 - Utilização dos referenciais intertextuais de Joseph Straus na rítmica da obra}

Os eventos rítmicos utilizados em cada compasso da composição foram extraídos dos frevos que mencionaremos mais adiante, utilizando seus formatos originais ou com variações: por aumentação (seus valores individuais serão alterados para outros maiores), por diminuição (valores individuais alterados para outros menores), por seccionamento (uso de parte do evento rítmico escolhido) ou por retrogradação (o evento rítmico ou parte dele foi escrito de trás para frente, com ou sem aumentação ou diminuição das figuras originais). No caso de um seccionamento, a parte não utilizada era desconsiderada ou preenchida por pausas. Além disso, em alguns trechos empregamos pausas antes ou durante os eventos rítmicos originais ou seccionados, deslocando-os ou provocando separação das porções obtidas pelo seccionamento.

Extraímos as células rítmicas do trecho mostrado na Figura 1 e dos primeiros compassos de cinco frevos de rua de um profícuo compositor pernambucano, Inaldo Moreira ${ }^{3}$. Da vasta lista de frevos de rua desse compositor, escolhemos obras contrastantes entre si e transcrevemos para uma tabela (Figura 6) todos os ritmos com duração de dois tempos (equivalentes ao preenchimento de um compasso de 2/4). Os frevos do compositor citado

\footnotetext{
2 Segundo MORRIS (1993, p.206), o contorno musical é um conjunto ordenado de n distintas alturas, com ou sem repetições, numeradas, e não necessariamente de forma adjacente.

${ }^{3}$ Cantor, clarinetista, premiado arranjador e compositor pernambucano, com diversas obras de vários gêneros gravadas em diversos CDs. Faleceu em 2017.
} 
LIMA, Flávio; ALVES, José Orlando. (2018) Um Planejamento composicional a partir de elementos do frevo de rua pernambucano. Per Musi. Belo Horizonte: UFMG. p.1-24.

anteriormente e que foram utilizados na presente pesquisa são: Quartetoidiando, Recordando Lito, Constantino leva a vida no abano (compostos no ano 2000), Guerra é paz no Frevo (composto em 2003) e Só vou de Val! (composto em 2001). Essas obras - a nossa composição e as cinco mencionadas anteriormente - forneceram, portanto, o material rítmico utilizado na composição da Criação no.3.

\begin{tabular}{|l|lll|}
\hline \multicolumn{1}{|c|}{ Frevo } & Eventos rítmicos existentes \\
\hline Frevo da Figura 1 &
\end{tabular}

Figura 6: Células rítmicas usadas nos 5 primeiros compassos dos 6 frevos relacionados até agora (desconsideramos as ligaduras de prolongamentos entre compassos)

A tabela existente na Figura 6 mostra os eventos rítmicos coletados e a Figura 7 exibe a frequência de aparecimento de cada um desses eventos rítmicos, tomando por base a totalidade das amostras. A metodologia da contagem das células rítmicas foi considerar cada aparição de uma célula como sendo uma unidade, independente de repetições. Utilizamos o seguinte princípio de amostragem: um saxofone alto apresentando uma célula rítmica, sem divisi com qualquer outro instrumento, foi considerada uma unidade no cômputo da aparição dessa célula; por outro lado, os trompetes executando "acordes" de quatro sons (ou mesmo um uníssono desses 4 instrumentos) e usando uma mesma célula rítmica, consideramos quatro unidades de aparição dessa célula e assim por diante. A Figura 7 foi organizada com valores crescentes de frequência de aparecimento das células e sua última coluna apresenta os percentuais obtidos. Esse procedimento resultou da utilização do conceito das proporções revisionárias abordadas por STRAUS (1990, p.17), em uma pesquisa de observação comparativa da intertextualidade verificada entre obras de compositores e épocas diversas. Nesse trabalho, STRAUS se refere à influência exercida de um compositor mais antigo em um mais recente e enumerou oito proporções revisionárias, sendo uma delas utilizada neste artigo. Em outras palavras, fizemos uma releitura das observações de STRAUS (1990, p.17), adaptamos os conceitos criados por ele à escolha dos eventos rítmicos que foram utilizados no quinteto. Uma dessas proporções revisionárias, a marginalização, foi aplicada nessa seleção e definiu as prioridades de utilização das células expostas na Figura 7. A marginalização, segundo STRAUS (1990, p.17, tradução nossa) consiste em elementos musicais que são centrais à estrutura do trabalho precedente são relegados à periferia das obras posteriores. Assim sendo, a proposição da marginalização aplicada à nossa pesquisa torna as células rítmicas 
LIMA, Flávio; ALVES, José Orlando. (2018) Um Planejamento composicional a partir de elementos do frevo de rua pernambucano. Per Musi. Belo Horizonte: UFMG. p.1-24.

mais frequentes - as da metade inferior da Figura 7 - menos utilizadas no quinteto, situação inversa à das situadas na metade superior.

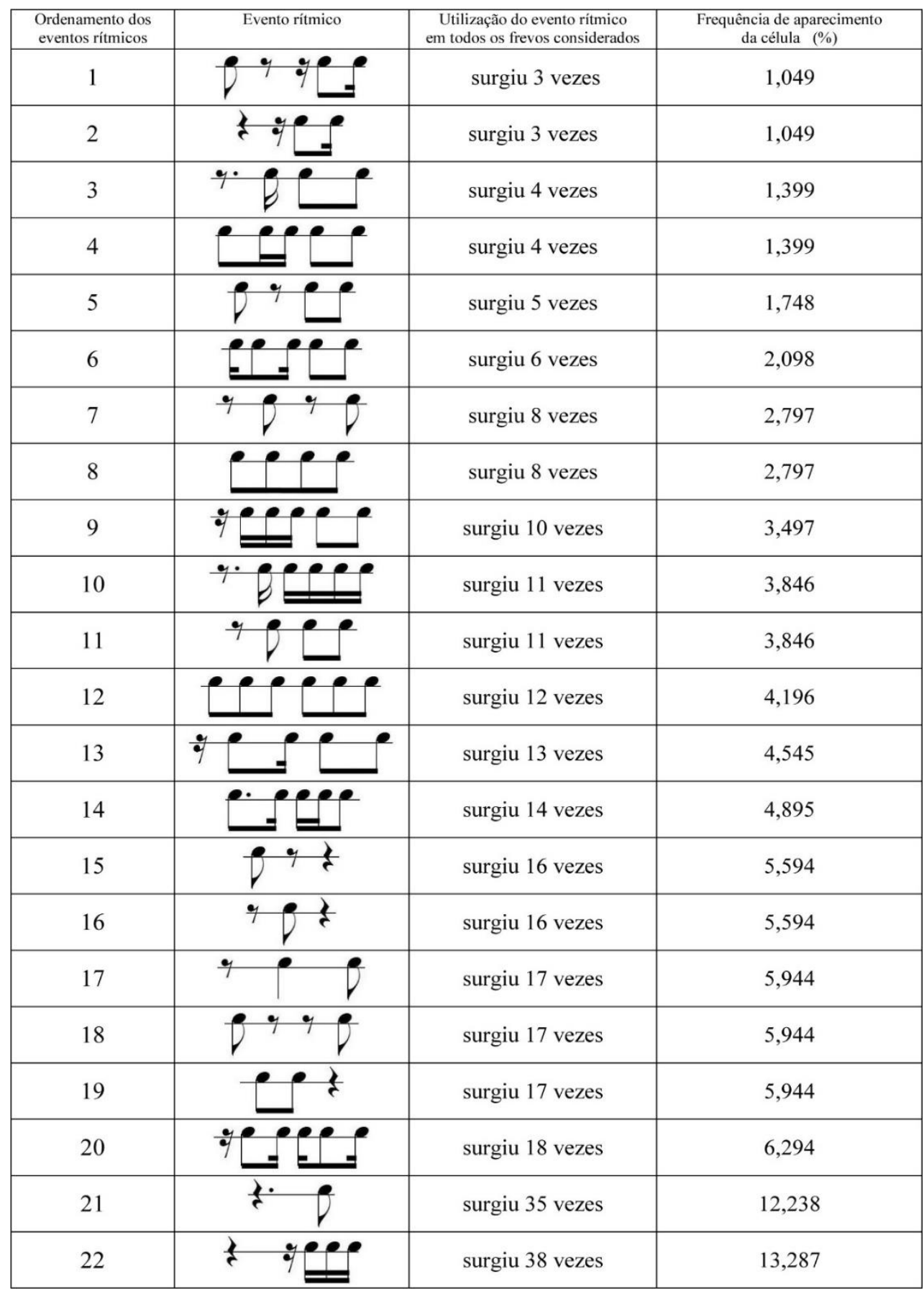

Figura 7: Tabela de eventos rítmicos, mostrados na Figura 6, em ordem crescente de aparecimento, e o percentual de frequência de cada célula. 


\section{3 - Elaborações timbrísticas na composição}

Utilizamos também o contorno para definirmos os timbres em cada compasso da composição. Para isso, consideramos que cada numeral da sequência <3 54253 1> corresponde à quantidade de timbres por compasso. Exemplificando, o numeral 3 equivale ao emprego de três timbres diferentes, ou seja, utilização de opções como trompete/trompa/tuba, trompa/trombone com surdina/tuba, trompete com surdina/trompete sem surdina/trombone, etc.; o numeral 5 , subsequente ao numeral 3 no contorno, representa a utilização de cinco timbres diferentes, por exemplo, um trompete sem surdina, um com surdina, uma trompa, um trombone e um tuba, etc. Enumerando os timbres disponíveis num quinteto de metais, chegamos a conclusão que podemos empregar as seguites opções: trompete com campânula aberta; trompete com surdinas (plunger, straight, harmon e cup), trompa, trombone (também com campânula aberta ou com o uso de surdina straight) e tuba, portanto, um total de nove timbres diferentes. A quinta coluna da Figura 10 organiza o planejamento e exibe a forma cíclica como os timbres foram previstos para cada compasso. Exemplificando, o primeiro compasso possui três timbres diferentes; o segundo, cinco timbres; o terceiro, quatro timbres; o quarto, dois timbres; o quinto, cinco timbres; o sexto, três timbres; e um único timbre no sétimo compasso. A partir do oitavo compasso, a sequência volta ao início e esse procedimento foi repetido ciclicamente até o final da peça, metodologia semelhante à elaboração da construção de gestos horizontais, conforme explicado anteriormente.

\section{4 - Definições da forma e o estabelecimento das características texturais}

Segundo LESTER, "a forma se refere às seções em uma peça: sua organização, o(s) tipo(s) da música que ela contém, e a relação de uma seção com outra” (LESTER, 1989, p.56, tradução nossa), e ainda fornece continuidade ao movimento ou composição (COOPER, 1963, p.151). Por outro lado, ZAMACOIS (1985, p. 3) define a forma como a organização de um conjunto de ideias musicais enquanto WENNERSTROM $(1975$, p.2) atesta a existência de vários tipos de forma utilizadas no século XX, muitas sem qualquer relação com o que se fazia até o século XIX.

0 frevo de rua tem, por tradição, forma fixa binária e é "composto de duas partes unidas por uma passagem ou ponte da qual participam todos os instrumentos" (CÁRDENAS, 1981, p. 55 - 56). Complementando a descrição desse perfil, OLIVEIRA (1971, p. 36) afirma que o frevo é bem semelhante a outras formas binárias, como o passo doble, o shimmy, a polca, o can-can. Optamos por utilizar na composição para quinteto de metais, o que WENNERSTROM $(1975$, p. 5) denominou de Forma Seccional, modalidade de construção musical referente ao "procedimento de usar vários arranjos de seções [ou 'partes'] bem definidas de música” (WENNERSTROM, 1975, p. 5, tradução nossa) ${ }^{4}$.

\footnotetext{
${ }^{4}$ Segundo a autora (WENNERSTROM, 1975, p. 2), cada seção tem um propósito e se encaixa com as demais para formar um grande complexo construído a partir do princípio de repetição, variação e contraste. As seções possuem contrastes entre si, e por isso adotamos o termo "parte" para as subdivisões desta peça, visto que os contrastes observados são escassos e pouco perceptíveis.
} 
Projetamos o quinteto para metais com sete partes (nomeados A, B, C, D, E, F, G), no entanto, mantivemos uma correspondência entre as partes e o contorno <3 542531 >. Para isso, definimos que a parte A tem uma relação com o numeral 3 do contorno, a parte B com o numeral 5, a parte C com o numeral 4, etc. Essa relação será abordada mais adiante quando mostrarmos como isso ocorreu e como desenvolvemos o equilíbrio formal da obra.

Em seguida, determinamos os aspectos texturais para cada uma das sete partes mencionadas no parágrafo anterior, conforme exposto mais adiante na Figura 8. Essas escolhas se basearam em situações descritas por BERRY (1987, p. 192), isto é, buscamos propriedades sonoras entre as diversas partes, fornecendo-lhes características próprias. Observando os eventos rítmicos da Figura 7, todo o quinteto foi construído sob uma heterorritmia generalizada - eventos rítmicos originais, seccionados ou invertidos - e conforme mostramos adiante no planejamento rítmico, considerando condições texturais não só homo, hetero ou contradirecionais, como também homo, hetero ou contraintervalares (BERRY, 1987, p. 192). Cada parte possui características que Berry denomina "sonoridade", pois sua construção utiliza articulações e dinâmicas diferenciadas. Exemplificando, a parte A foi escrita sob dinâmicas $p$ e $f$ súbitas (segundo Berry, a "coloração" do trecho) e toda com alternâncias entre staccato e notas adjacentes com ligaduras, e acentuações ocasionais. Em contrapartida, a parte B foi concebida em dinâmica $m f$ e diferentemente da parte anterior, com uso de crescendos e diminuendos. Essas características texturais, bem como os aspectos dinâmicos, dão a cada parte peculiaridades sonoras, com identidade própria, conforme podemos verificar observando a Figura 8. Em toda a peça ocorre diversificação nas variações dinâmicas e articulações, e as fórmulas de compasso possuem numeradores iguais a cada elemento do contorno.

O contorno foi, como discorremos até agora, o principal agente norteador da concepção de diversos elementos paramétricos da composição. Entretanto, para o caso do cálculo do número de compassos para cada parte, propusemos que o contorno participasse de forma indireta nesse dimensionamento. Ou seja, uma proposição matemática foi formulada como segue: "o quadrado de um numeral índice $n$, subtraindo-se o quadrado do numeral índice n-1, resultará no quadrado do numeral índice n-2". Tal postulado não se aplica aos dois primeiros valores, pois são fixados como os quadrados de 5 e de 4, respectivamente (ou seja, 25 e 16), numerais fundamentais para os resultados da proposição. A partir do terceiro numeral, no entanto, o cálculo foi feito conforme segue: [(X5)2 - (X4)2 $=25-16$ $=(X 3) 2=9],[(X 4) 2-(X 3) 2=16-9=(X 2) 2=7]$ e $[(X 3) 2-(X 2) 2=9-4=(X 1) 2=5] . A$

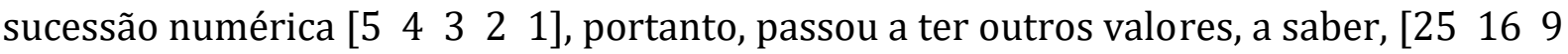
7 5]. Substituindo os elementos de mesma ordem nas sequências mostradas há pouco (5 por 25, 4 por 16, 3 por 9, 2 por 7 e 1 por 5), o contorno <3 542531 > passou a ser constituído de novos elementos, $<\begin{array}{lllllll}9 & 25 & 16 & 7 & 25 & 9 & 5>\text {, e cada elemento desse novo }\end{array}$ ordenamento definiu o número de compassos para cada parte da composição. A Figura 8 apresenta as partes com suas respectivas dimensões, texturas e fórmulas de compasso. 
LIMA, Flávio; ALVES, José Orlando. (2018) Um Planejamento composicional a partir de elementos do frevo de rua pernambucano. Per Musi. Belo Horizonte: UFMG. p.1-24.

\begin{tabular}{|c|c|c|c|c|}
\hline 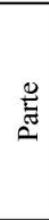 & 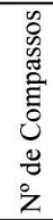 & Dinâmicas & Articulações e rítmica & 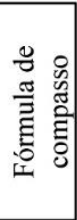 \\
\hline $\mathrm{A}$ & 9 & $\begin{array}{l}-p \text { e } f \text { súbitos em } \\
\text { alternância }\end{array}$ & $\begin{array}{l}\text { - staccatos e notas adjacentes ligadas em alternância; ligaduras nos } \\
\text { trinados; acentuações }(>\text { ) } \\
\text { - uso de seccionamento e retrogradação de eventos rítmicos } \\
\text { - célula rítmica original do frevo (com ou sem seccionamentos ou } \\
\text { mudanças de instrumento) e possibilidade de repetições de segmentos no } \\
\text { ritmo de frevo. }\end{array}$ & $3 / 4$ \\
\hline B & 25 & $\begin{array}{l}\text { - intensidades em } m f \\
\text { - uso de crescendos e } \\
\text { diminuendos alternados. }\end{array}$ & $\begin{array}{l}\text { - notas sustentadas; uso de tenuto e acentuações }(s f z,>) \\
\text { - uso dos eventos rítmicos em sua forma original ou com aumentações, } \\
\text { diminuições, secionamentos e retrogradações. } \\
\text { - utilização de ligaduras de frase e de prolongamentos. } \\
\text { - célula rítmica original do frevo ou com aumentações (com ou sem } \\
\text { seccionamentos ou mudanças de instrumento) e possibilidade de } \\
\text { repeticões de fragmentos da célula do frevo. }\end{array}$ & $5 / 4$ \\
\hline $\mathrm{C}$ & 16 & $\begin{array}{l}\text { - intensidades em } p \\
\text { - utilização única de } \\
\text { crescendos apenas nas } \\
\text { notas sustentadas, com } \\
\text { valores iguais ou } \\
\text { superiores à semínima }\end{array}$ & $\begin{array}{l}\text { - uso de staccato em figuras iguais ou menores que colcheia ou ligaduras } \\
\text { em notas adjacentes (iguais ou menores a colcheia). } \\
\text { - uso de ligaduras nos trinados; uso de tenuto em notas maiores que a } \\
\text { colcheia. } \\
\text { - uso de eventos rítmicos originais ou com aumentações, diminuições, } \\
\text { seccionamentos ou retrogradações rítmicas. } \\
\text { - acentuações }(>\text { ) eventuais nas notas curtas (menores que semínima). } \\
\text { - ritmo do frevo original ou com aumentações (com ou sem } \\
\text { seccionamentos ou mudanças de instrumento) }\end{array}$ & $4 / 4$ \\
\hline $\mathrm{D}$ & 7 & $\begin{array}{l}\text { - } m f \text { e } f f \text { súbitos em } \\
\text { alternância. }\end{array}$ & $\begin{array}{l}\text { - utilização dos eventos rítmicos originais, ou com o uso de } \\
\text { retrogradações e seccionamentos. } \\
\text { - uso de staccatos; e em menor número, de acentos }(>) \\
\text { - célula rítmica original do frevo, ou com seccionamentos e } \\
\text { prolongamentos. }\end{array}$ & $2 / 4$ \\
\hline $\mathrm{E}$ & 25 & $\begin{array}{l}\text { - } p \text { e } f \text { súbitos em } \\
\text { alternância }\end{array}$ & $\begin{array}{l}\text { - notas sustentadas (sem staccatos, só uso de tenuto e acentos) } \\
\text { - uso de eventos rítmicos em sua forma original, ou com o uso de } \\
\text { aumentações, diminuições, secionamentos ou retrogradações. } \\
\text { - utilização de acentuações (sf, <) } \\
\text { - utilização de ligaduras de frase e de prolongamentos }\end{array}$ & $5 / 4$ \\
\hline $\mathrm{F}$ & 9 & $\begin{array}{l}\text { - intensidades em } f \\
\text { - utilização de diminuendos } \\
\text { (em notas sustentadas e } \\
\text { grupo de notas) }\end{array}$ & $\begin{array}{l}\text { - uso único de aumentações rítmicas (à exceção da célula rítmica original } \\
\text { do frevo, vide EX 1.6, utilizada com figuras nos seus valores originais, } \\
\text { possibilitando ainda seccionamentos com ou sem prolongamentos, } \\
\text { repetições de segmentos e retrogradações). } \\
\text { - notas curtas em staccato (menores que a colcheia), podendo-se também } \\
\text { existir ligaduras entre notas adjacentes menores ou iguais a colcheia } \\
\text { - notas sustentadas (maiores ou iguais que a colcheia) } \\
\text { - uso de acentuações (< e } s f \text { ) } \\
\text { - uso exclusivo de ligaduras em trilos do ritmo de frevo }\end{array}$ & $3 / 4$ \\
\hline G & 5 & $\begin{array}{l}\text { - intensidades em } m f \text { e } p \\
\text { - utilização de diminuendos } \\
\text { (em notas com maior } \\
\text { duração ou grupo de notas) }\end{array}$ & $\begin{array}{l}\text { - ritmos originais, com uso exclusivo de seccionamentos ou } \\
\text { retrogradações. } \\
\text { - uso de staccato em figuras menores que colcheia. } \\
\text { - uso de sustentação em notas iguais ou maiores que colcheia. } \\
\text { - ritmo de frevo original sem alterações rítmicas, e uso exclusivo de } \\
\text { ligaduras nos trinados. }\end{array}$ & $1 / 4$ \\
\hline
\end{tabular}

Figura 8: Tabela com número de compassos, dinâmicas, texturas e fórmulas de compasso, de cada uma das sete partes constitutivas da peça (A a G).

Como último detalhe composicional a ser considerado, faremos o uso da célula rítmica original do frevo como uma estrutura que, de forma intermitente, perpassa todo o quinteto de metais. Essa célula é comum a todos os frevos pernambucanos e é executada basicamente por uma caixa e pelo bombo ou surdo (doze semicolcheias com acentos específicos seguidos por um rullo, conforme a Figura 9). Utilizamos essa célula não só como se apresenta na figura abaixo, mas também empregando as seguintes variações: 
seccionamentos (prolongamentos sonoros ou interrupções com o uso de pausas), aumentações, diminuições ou inversões (iniciar com o trinado e executar a célula em sentido contrário, de frente para trás). Isolamos os processos de variação da célula do frevo das demais expostas na Figura 7 porque pretendemos, como veremos adiante, manusear de forma independente essas estruturas. Enquanto a primeira - a da célula da Figura 9 - é apresentada de forma sequenciada e quase linear no transcurso da composição, as outras são trabalhadas de forma simultânea ou coincidente, raramente empregadas em uma forma contínua. Assim sendo, aplicamos as aumentações, diminuições, inversões e seccionamentos em um grau mais cuidadoso na célula do frevo que nos demais eventos rítmicos, pela inteligibilidade que a primeira oferece, conforme explicaremos em seguida.

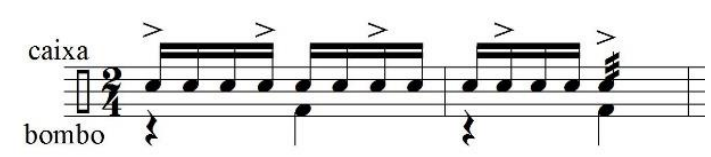

Figura 9: Célula rítmica original do frevo.

O vocábulo "inteligível”, segundo HOUAISS (2011, p.545), significa "que se entende, claro", e o termo "inteligibilidade", segundo a mesma publicação, é "o que pode ser compreendido". Por outro lado, SCHOENBERG $(2008$, p.47) afirma que "a inteligibilidade musical parece ser algo impossível de se obter sem o recurso de repetição". Considerando que é nosso objetivo tornar inteligível, em graus diversificados, essa célula rítmica original do frevo pelo recurso da recorrência, SCHOENBERG $(2008$, p.48) orienta que "a discrição é especialmente necessária quando se almeja uma inteligibilidade imediata", preservando e justificando nosso objetivo. A célula rítmica do frevo, portanto, executa continuamente evoluções diferenciadas no decorrer da peça, entretanto, participa do contexto geral de uma maneira ao mesmo tempo instavelmente inteligível e discreta.

Uma informação adicional a respeito do caráter inteligível da célula da Figura 9 diz respeito à preocupação que tivemos em não torná-la apenas uma reprodução literal conforme execuções originais do frevo. Evitamos recair em uma interpretação errônea do ouvinte, de que estivéssemos tão somente compondo sob a inspiração de uma linguagem musical do século XX mas em ritmo de frevo, o que não é a realidade. 0 manuseio descrito anteriormente evita essa apreciação equivocada, além de, como já mencionamos, enriquecer a sonoridade da obra. A intenção da inteligibilidade é rememorar a rítmica básica do frevo sem torná-la trivial e "participando efetivamente do contexto da obra e com discrição que varia de acordo com o conteúdo do trecho que a rodeia" (SCHOENBERG, 2008, p.47).

O segundo tempo do segundo compasso dessa célula, o rullo, também foi em certas ocasiões substituído por seis semicolcheias em tercinas, oito fusas, frulatto, ou mesmo trinado com notas auxiliares em intervalos iguais ou maiores que uma segunda, obedecendo sempre à ordem de aparecimento das alturas previstas na Figura 5. A escolha do(s) instrumento(s) que executa(m) a célula do frevo foi arbitrária e utilizamos artifícios criativos como reforços aos acentos (sobre a primeira, a quarta, a sétima e a décima figura), execução da célula por um instrumento (sem os acentos) e as alturas acentuadas 
por outro(s), etc. Essas decisões composicionais enriqueceram a sonoridade da obra e as aparições do elemento de inteligibilidade (a célula rítmica do frevo) se prestaram como elo entre as linguagens abordadas neste artigo. 0 resultado foi uma sonoridade atonal e distante do ambiente tonal que ouvimos nos frevos pernambucanos.

\section{5 - Planejamento da composição}

A Figura 10 apresenta grande parte do planejamento macro-estrutural ${ }^{5}$ do quinteto de metais. A primeira coluna mostra cada parte da composição e a segunda, a numeração dos compassos. As demais colunas apresentam as características básicas estabelecidas anteriormente: as alturas, eventos rítmicos, timbres e fórmulas de compasso. Esses parâmetros, as texturas definidas e mostradas na Figura 10, bem como a célula rítmica original do frevo (Figura 9) constituíram a matéria prima para a construção da obra para quinteto de metais.

\begin{tabular}{|c|c|c|c|c|c|}
\hline 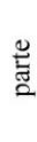 & $\begin{array}{c}\mathrm{n}^{\mathrm{o}} \text { do } \\
\text { compasso }\end{array}$ & $\begin{array}{l}\text { Ordenamento de } \\
\text { Alturas } \\
\text { (conf. QUAD. 2.1) }\end{array}$ & $\begin{array}{c}\text { Eventos rítmicos (conforme } \\
\text { TAB. } 2.1 \text { ) }\end{array}$ & $\begin{array}{l} \\
\therefore \\
0\end{array}$ & 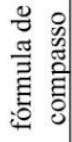 \\
\hline \multirow[t]{9}{*}{ A } & \multirow[t]{9}{*}{1 a 9} & \multirow[t]{10}{*}{ Ordenamento A' } & \multirow[t]{9}{*}{ Eventos Rítmicos 1 a 4, 13 e 14} & 3 & \multirow[t]{9}{*}{$3 / 4$} \\
\hline & & & & 5 & \\
\hline & & & & 4 & \\
\hline & & & & 2 & \\
\hline & & & & 5 & \\
\hline & & & & 3 & \\
\hline & & & & 1 & \\
\hline & & & & 3 & \\
\hline & & & & 5 & \\
\hline \multirow[t]{23}{*}{ B } & 10 & & \multirow{23}{*}{ Eventos Rítmicos 5 a 8,15 e 16} & 4 & \multirow[t]{23}{*}{$5 / 4$} \\
\hline & \multirow[t]{9}{*}{11 a 20} & \multirow[t]{9}{*}{ Ordenamento B' } & & 2 & \\
\hline & & & & 5 & \\
\hline & & & & 3 & \\
\hline & & & & 1 & \\
\hline & & & & $\frac{3}{5}$ & \\
\hline & & & & 4 & \\
\hline & & & & 2 & \\
\hline & & & & 5 & \\
\hline & & & & 3 & \\
\hline & \multirow[t]{9}{*}{21 a 30} & \multirow[t]{9}{*}{ Ordenamento C' } & & 1 & \\
\hline & & & & 3 & \\
\hline & & & & 5 & \\
\hline & & & & 4 & \\
\hline & & & & 2 & \\
\hline & & & & 5 & \\
\hline & & & & 3 & \\
\hline & & & & 1 & \\
\hline & & & & 3 & \\
\hline & \multirow{4}{*}{31 a 34} & \multirow{4}{*}{ Ordenamento D' } & & 5 & \\
\hline & & & & 4 & \\
\hline & & & & $\frac{2}{5}$ & \\
\hline & & & & $\frac{5}{3}$ & \\
\hline
\end{tabular}

\footnotetext{
5 “O planejamento macroestrutural pode ser entendido aqui com base nos procedimentos prévios, em torno do direcionamento das ideias musicais, que colaboram para a configuração da peça como um todo, caracterizando também partes ou seções" (ALVES, 2010, p.161)
} 
LIMA, Flávio; ALVES, José Orlando. (2018) Um Planejamento composicional a partir de elementos do frevo de rua pernambucano. Per Musi. Belo Horizonte: UFMG. p.1-24.

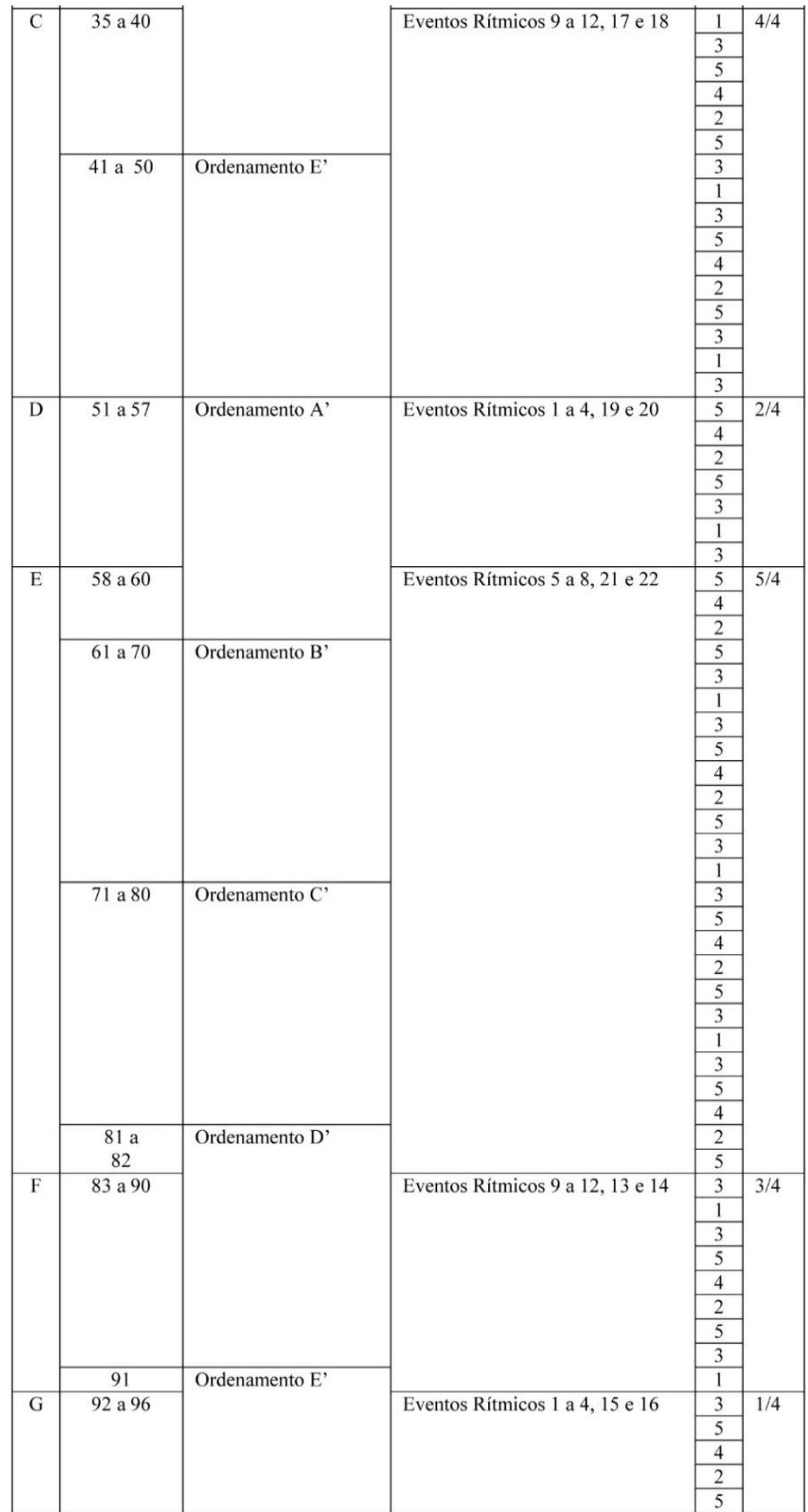

Figura 10: Tabela com compassos, contornos, eventos rítmicos, número de timbres e fórmulas de compasso das partes da composição.

Abaixo estabelecemos as legendas úteis na identificação dos parâmetros manipulados, na partitura, e previstos no presente planejamento. Constam nessa relação: a visualização das sequências de alturas previstas na Figura 5 (ordenamento A', B', C', etc); os segmentos 
rítmicos utilizados (modificados ou não); o número de timbres (1 a 5); as letras correspondentes às partes $(\mathrm{A}$ a $\mathrm{G})$; e a identificação da célula rítmica do frevo e como foi utilizada, elemento de inteligibilidade intermitente por toda a obra.

a. A indicação da parte é mostrada com letras tamanho grande (fonte 18, negrito), sobre a barra de compasso que o inicia. Ao lado dessa letra encontra-se o número de timbres diferentes, referente a cada compasso. Exemplificando, um A seguido por um número 3 significa que o referido compasso em questão pertence à parte $\mathrm{A}$ e possui 3 timbres diferentes.

b. Os ordenamentos de altura são identificados acima de cada linha melódica. Por exemplo, ord. A (abreviação de ordenamento A) significa que esse ordenamento é iniciado pela primeira altura prevista na Figura 5; ord. A'- m, por outro lado, significa que não é iniciado pela primeira altura.

c. O evento rítmico é assinalado da seguinte forma: ER-X, onde ER é a abreviatura de evento rítmico e o $\mathrm{X}$ indica que está na forma original. Nos casos em que utilizamos processos de aumentação, diminuição, seccionamento ou inversão, indicamos como ER-Xn, onde X representa o numeral do evento rítmico (Figura 7, coluna "ordenamento dos eventos rítmicos"), e o n, a abreviação do processo de variação rítmica, isto é: "a" quando houve aumentação, "d" uma diminuição, "s" um seccionamento e "i" uma inversão. Como exemplificações: ER-1, indica que utilizamos a célula original 1, na sua conformação original mostrada na Figura 7; ER-12s representa o evento rítmico 12 da Figura 7, porém seccionado, isto é, só utilizamos parte dele; ER-15s/a representa o evento rítmico 15 (Figura 7), seccionado e com aumentação do(s) valor(es) da(s) figura(s); ER-20d representa o evento rítmico 20 (Figura 7), com diminuição dos valores das figuras; ER-26i representa o evento rítmico 26 (Figura 7) invertido; etc. Quando utilizamos aumentação ou diminuição, a manipulação das figuras não é obrigatoriamente proporcional. No entanto, todos os valores da célula passam pelo processo variacional.

d. 0 elemento de inteligibilidade (Figura 9) é identificado pelo termo RF, abreviação de Ritmo de Frevo, e quando este se prolongava para outro instrumento, a indicação RF é numerada. Nesse caso, cada segmento desse ritmo é identificado como $R F(1), R F(2)$, $R F(3)$, etc. Nas ocasiões em que o ritmo de frevo (ou parte dele) permanecia num mesmo instrumento, o termo é posto no início e seguido por uma linha indicando onde ele finalizava. Da mesma maneira como indicado no item anterior da bula, variações rítmicas do ritmo do frevo são marcadas como RFa (ritmo de frevo com aumentação), RFs (ritmo de frevo com seccionamento) e RFi (ritmo de frevo com inversão). A repetição do trinado pelo mesmo instrumento ou instrumentos diferentes, é indicada por trinado1, trinado2, etc. Outras indicações são escritas por extenso, como "reforços dos acentos do RF", "RF(1)repetido", etc. Utilizamos segmentos de reta para mostrar o alcance das indicações analíticas presentes na partitura. A título de exemplificação, as tres primeiras páginas da composição, com o emprego das legendas acima descritas, encontram-se no apêndice deste artigo, juntamente com as demais páginas da peça em versão para publicação e execução. 


\section{6 - A aplicação composicional}

Organizadas as tabelas apresentadas nas Figuras 5, 7, 8, 9 e 10, o procedimento de escritura da composição propriamente dita iniciou após concluirmos anotações auxiliares, relacionando de maneira condensada tudo o que seria utilizado em cada compasso, viabilizando uma consulta rápida. Assim sendo, a obra - que tema duração aproximada de quatro minutos - começou a ser escrita a partir do princípio, do primeiro compasso, observando-se o material previsto conforme mencionamos há pouco. Todas as escolhas, considerando-se as disponibilidades existentes, possibilitaram o distanciamento de sonoridades tonais, o não sincronismo rítmico e os resultados contrastantes, bem como contrapontísticos foram sempre buscados por toda a composição. Naturalmente, observando-se o efeito provocado pelas evoluções contrapontísticas, os ápices sonoros ocorreram onde foram utilizados cinco timbres, ou seja, os c.2, 5, 9, 12, 16, etc. (vide quinta coluna da Figura 10 e Figura 11).

Em várias ocasiões, utilizamo-nos de retroalimentações com uso de eventos rítmicos iguais, no entanto, com variações na escolha das alturas e dos instrumentos executantes. Também alguns artifícios sonoros foram utilizados, como entradas em defasagens, pirâmides, etc., mas sem fugir dos preceitos pré-estabelecidos no planejamento. Os cinco compassos da seção G, pelas características conclusivas que apresentam (seção com trecho breve com características diferenciadas das demais seções, figuras curtas, dinâmicas suaves e pouco contrastantes, final abrupto), foram considerados como a coda.

No Apêndice deste artigo, apresentamos a partitura da peça, mostrando não só a utilização dos elementos tabelados nas Figuras 5 (ordenamentos de alturas), 7 (eventos rítmicos), 8 (número de compassos, dinâmicas, texturas e fórmulas de compasso) e 10 (contornos, eventos rítmicos, número de timbres e fórmulas de compasso), como também de que forma surge a célula da Figura 9 no decorrer da composição. Assim, tomando a parte A como amostra, verificamos que parte do ritmo de frevo é executado na seguinte ordem: pela trompa no c.1, e concluído pelo trombone no c.2; em seguida, este último instrumento o reinicia, executa-o em parte e com algumas variações de repetição, é sucedido pela trompa e o segundo trompete, que são envolvidos no contexto da célula da Figura 9; por fim, os c.5-9 apresentam exposições do ritmo de frevo com instrumentos que fazem suas intervenções parciais nessa sequência: trompa (um compasso inteiro e mais um tempo), trompete 2 (quatro tempos), trompete 1 (um tempo), trompa (três tempos); finalizamos a sequência de momentos inteligíveis do ritmo na parte A com um prolongamento de dois tempos do rullo (em forma de trinado), pelo trombone e a trompa (c.9).

O quinteto de metais Criação $n^{o} 3$ é dedicado ao Grupo Instrumental de Pernambuco, formado no ano de 2014 por renomados professores e músicos da Região Metropolitana do Recife. Foi executado em 29 de abril de 2016, no auditório Cussy de Almeida do Conservatório Pernambucano de Música, dentro da Série "Projetos Especiais - Cesta de Música", com a presença de todos os compositores vivos cujas peças foram executadas na ocasião, em primeira audição mundial. 0 áudio e a partitura completa da peça (versão para execução) encontram-se no link https://youtu.be/NsDkvUpLStc 


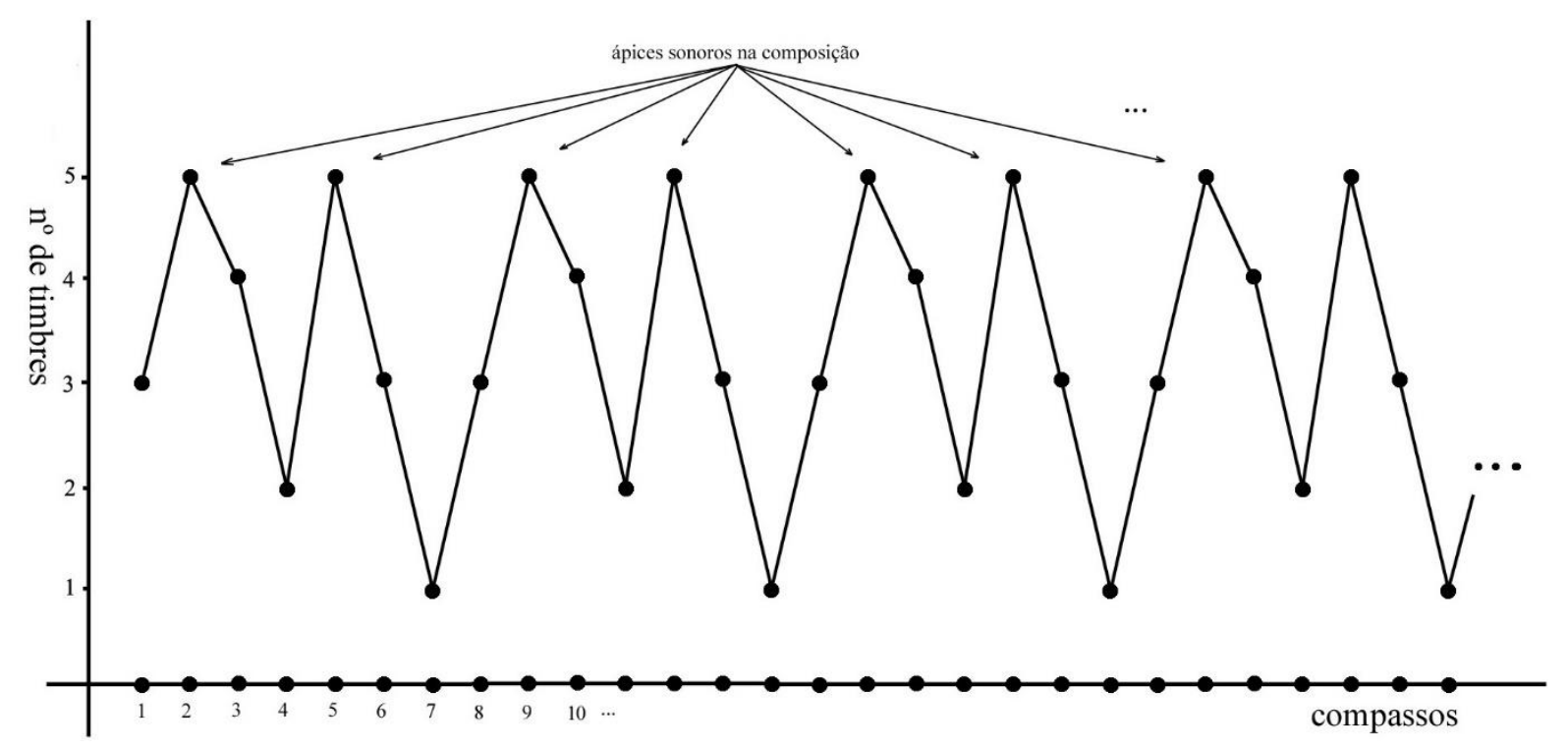

Figura 11: Evolução do número de timbres e os pontos de maior sonoridade.

\section{7 - Considerações finais}

Propusemos a fusão entre duas linguagens musicais distintas, a primeira refere-se ao frevo de rua pernambucano, um dos gêneros da música popular brasileira e a segunda, a música atonal, surgida e desenvolvida a partir do século XX. Optamos pelo procedimento que utiliza o ordenamento de alturas escolhido em função da aplicação da Teoria dos Contornos e, para que isso ocorresse, obtivemos uma sequência numérica (o contorno) a partir da redução de uma frase musical existente no início do frevo Nuneziando, composto por Flávio Lima, utilizando técnicas analíticas simples. Esse contorno obtido e que se tornou a gênese da elaboração dos elementos musicais para a nova composição, determinou os gestos horizontais, a forma, o timbre e as fórmulas de compasso. A escolha das células rítmicas que foram utilizadas no quinteto derivou da extração de amostragens existentes nos cinco primeiros compassos de alguns frevos de rua.

Uma das proposições revisionárias de STRAUS (1990), a marginalização, foi utilizada possibilitando um ordenamento das células rítmicas através da frequência estatística de aparecimento das mesmas nos frevos escolhidos para a pesquisa. Como elo entre o gênero popular e aspectos da música de concerto do século XX, fundidos na presente pesquisa, utilizamos a célula rítmica original do frevo, mostrado na Figura 9, em graus variados de abstração.

Tabelamos, enfim, as informações principais do planejamento a serem utilizadas no ato composicional (Figuras 8 e 10) contendo as texturas, as dinâmicas, as articulações, as manipulações das células e eventos rítmicos e as fórmulas de compasso. Concluído o planejamento, elaboramos legendas para a identificação da simbologia utilizada na partitura, um auxílio analítico que mostra a ação composicional conforme planificado. Em suma, cada procedimento descrito no artigo integra-se ao objetivo da criação 
LIMA, Flávio; ALVES, José Orlando. (2018) Um Planejamento composicional a partir de elementos do frevo de rua pernambucano. Per Musi. Belo Horizonte: UFMG. p.1-24.

composicional de forma efetiva, fornecendo todo o material paramétrico necessário. Além da nossa proposição composicional, reflexões a respeito de outras variantes desses procedimentos poderão ser feitas, para novos resultados. Exemplificando, apontamos possibilidades de emprego de outros contornos provenientes de outros frevos (ou de outros gêneros musicais, populares ou não) e revelando novos gestos horizontais, uso de outras formações instrumentais (novos timbres), novas texturas com maior ou menor grau de contrastes, novas maneiras de estruturar a forma e os tipos de compassos utilizados a partir do contorno inicial, etc.

Este planejamento integra a Tese "A Teoria dos Contornos aplicada à Fusão Paramétrica do Frevo de Rua Pernambucano: inter-relações com aspectos da Música de Concerto do Séc. XX" (LIMA, 2018), que tem como linha de pesquisa principal a agregação de características encontradas no gênero popular "frevo" - modalidade de frevo de rua - e manifestações musicais surgidas na música de concerto do século XX. A pesquisa abordou a Teoria dos Contornos, a fusão direcionada à música, aspectos da intertextualidade aplicados à composição através dos estudos de STRAUS (1990), abordagens texturais, formais e timbrísticas, além das técnicas e procedimentos composicionais como o serialismo, o minimalismo, as massas sonoras e a modulação métrica. Concluímos que a proposta da pesquisa, descrita neste artigo, alcançou o objetivo esperado, por ter resultado em uma obra atonal não serial, o quinteto Criação $n^{\circ} 3$ para metais, cuja composição seguiu todo o planejamento proposto, desencadeando uma consequente reflexão para futuras pesquisas. Assim, esperamos que este artigo seja útil e inspirador na formulação de novos planejamentos composicionais e novas peças musicais, estruturadas a partir da fusão entre linguagens distintas.

\section{Referências}

1. ALVES, J. O. (2010). Aspectos do planejamento macro-estrutural da peça Intervenções II para Orquestra Sinfônica. In: CONGRESSO DA ASSOCIAÇÃo NACIONAL DE PESQUISA E PÓS-GRADUAÇÃO EM MÚSICA (ANPPOM), 20, 2010, Florianópolis. Anais... Florianópolis: UDESC, 2014.

2. BERRY, W. (1987). Structural Functions in Music. New York: Dover Publications.

3. CÁRDENAS, C. O. (1981). O uso do Folclore na Educação: o Frevo na Didática Pré-escolar. Recife: Editora Massangana.

4. COOPER, G.; MEYER, L.B. (1963). The Rhythmic of Structure of Music. Chicago: The University of Chicago Press.

5. FRAGA, O. (2011). Progressão Linear: uma breve introdução à Teoria de Schenker. Londrina: Eduel.

6. GUEST, I. (1996). Arranjo: Método Prático. v.1. Rio de Janeiro: Lumiar Editora.

7. HOUAISS, A.(org.) (2011). Inteligível. In: Dicionário Houaiss Conciso. São Paulo: Editora Moderna Ltda.

8. LESTER, J. (1989). Analytic Approaches to Twentieth-Century Music. New York: W. W. Norton \& Company, Inc. 
LIMA, Flávio; ALVES, José Orlando. (2018) Um Planejamento composicional a partir de elementos do frevo de rua pernambucano. Per Musi. Belo Horizonte: UFMG. p.1-24.

9. LIMA, F. (2018). A Teoria dos Contornos aplicada à Fusão Paramétrica do Frevo de Rua

Pernambucano: inter-relações com aspectos da Música de Concerto do Séc. XX. Tese de Doutorado,em Música. João Pessoa-PB, Universidade Federal da Paraíba.

10. MORRIS, R.D. (1987). Composition with pitch-classes: A theory of compositional design. New Haven: Yale University Press.

11. Spectrum, xv: p.205-28. (1993). New Directions in the theory and analysis of musical contour. Music Theory

12. OLIVEIRA, V. (1971). Frevo, Capoeira e Passo. Recife: CEPE.

13. PEASE, T.; PULLING, K. (2001). Modern Jazz Voicings: Arranging for Small and Medium Ensemble. Boston: Berklee Press.

14. SCHOEnBerg, A. (2008). Fundamentos da Composição Musical. 3a ed. Trad. Eduardo Seincman. São Paulo: Editora da Universidade de São Paulo.

15. STRAUS, J.N. (1990). Remaking the Past: Musical Modernism and the Influence of the Tonal Tradition. USA: Harvard University Press.

16. WENNERSTROM, M. (1975). Form in Twentieth-Century Music. In: Aspects of $2^{\text {th }}$ Century Music. Wittlich, G.E. (Ed.). New Jersey: Prentice-Hall, Inc.

17. ZAMACOIS, J. (1985). Curso de Formas Musicales. Spain: Labor.

Notas sobre os autores

Flávio Fernandes de Lima, recifense, Licenciado em Música (UFPE, 2007), Pós-Graduado em Coordenação Pedagógica pela UNICAP, Bacharel em Música (UFPB, 1984), Docente do Instituto Federal de Pernambuco campus Recife (a partir de 2015, ensino, pesquisa e extensão) e ex-professor do Curso de Licenciatura em Música do campus de Belo Jardim, 2010 a 2014. Músico profissional, trombonista da OSR por 26 anos e da OSPB por 4. Experiência no ensino de metais, instrumentação, interpretação trombonística e pianística (erudito e popular), composição, arranjos, orquestração, regência orquestral e de banda. Concluiu o Mestrado em 2011, pelo PPGM-UFPB, orientado pelo Prof. Dr. Liduíno Pitombeira. Integrante do Grupo de Análise Musical GAMAG, e hoje é Doutorando em Composição, pelo PPGM-UFPB, orientado pelo prof. Dr. José Orlando Alves.

José Orlando Alves, natural de Lavras (MG), é Bacharel e Mestre em Composição Musical pela UFRJ e Doutor em Música - Processos Criativos - pela UNICAMP (2005). Professor Associado de Composição Musical da UFPB. Faz parte do grupo Prelúdio 21. Premiado em 1. - lugar no Primeiro Concurso FUNARTE de Composição, na "Duos". 1. lugar com a obra Quantum, para quinteto de sopros (VII Concurso Nacional de Composição, IBEU), Menção Honrosa no Concurso Nacional de Composição Camargo Guarnieri (USP) e no concurso internacional Opus Dissonus (piano solo). Publicou em diversas revistas, anais de congressos e colóquios de pesquisa (OPUS, Claves, Hodie). Contemplado pela FUNARTE com encomenda composicional, Bienal de 2013. Premiado no concurso FUNARTE DE COMPOSIÇÃO CLÁSSICA 2014, na categoria orquestra de cordas. 


\section{Apêndice}
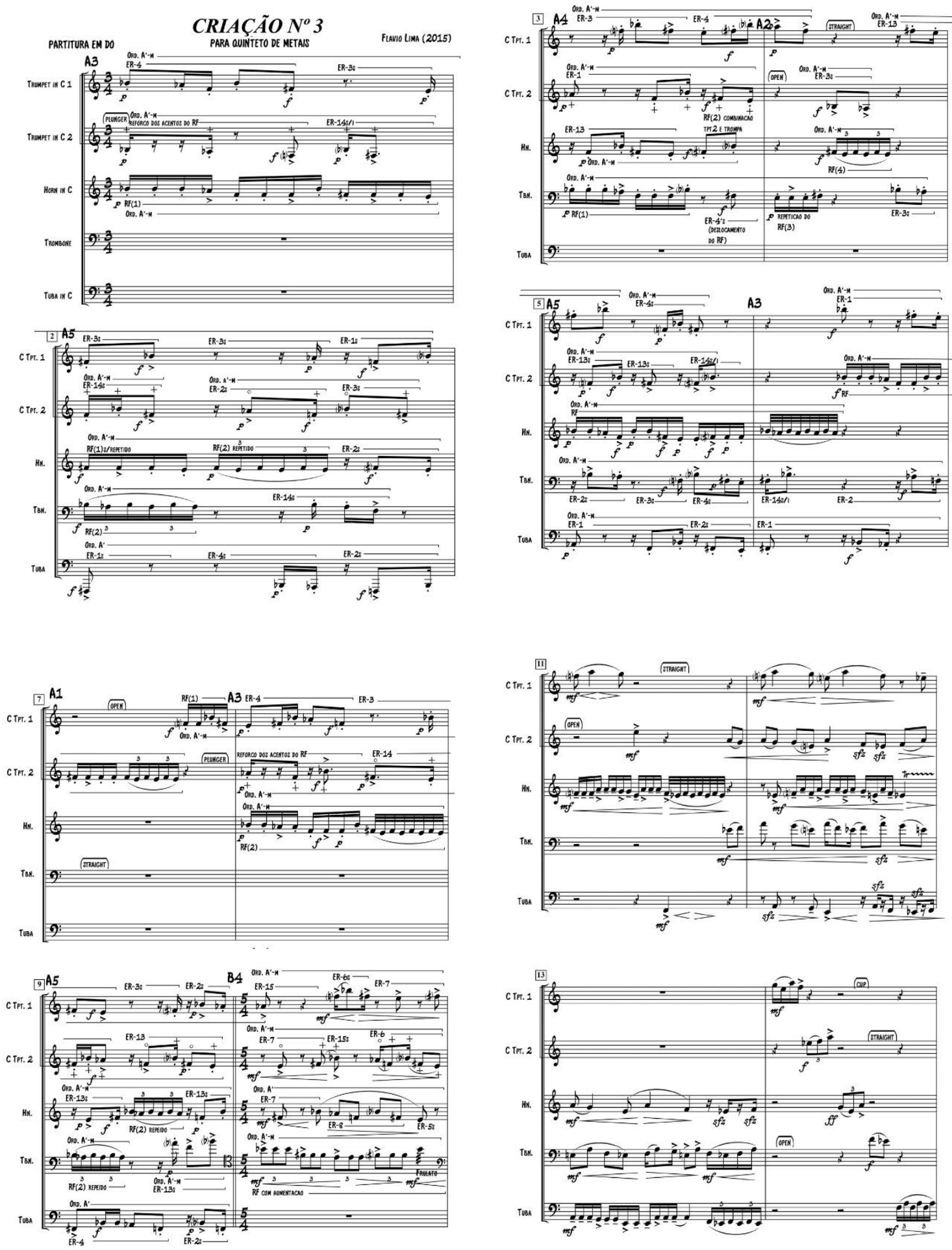

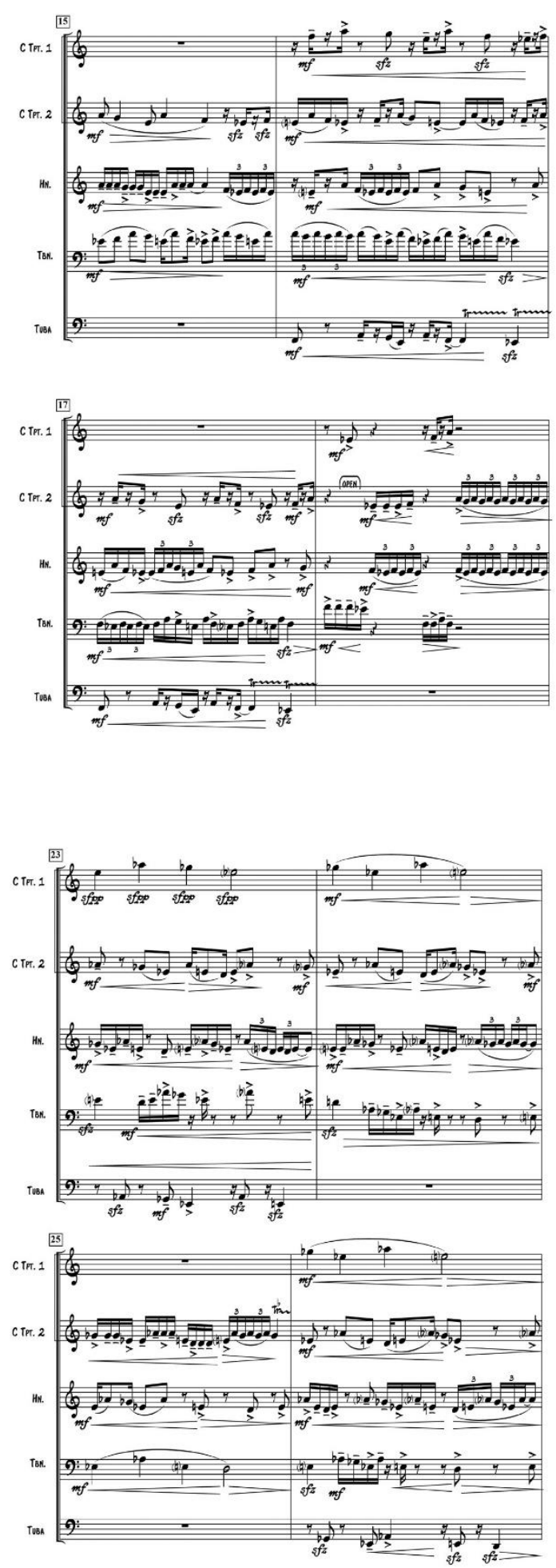
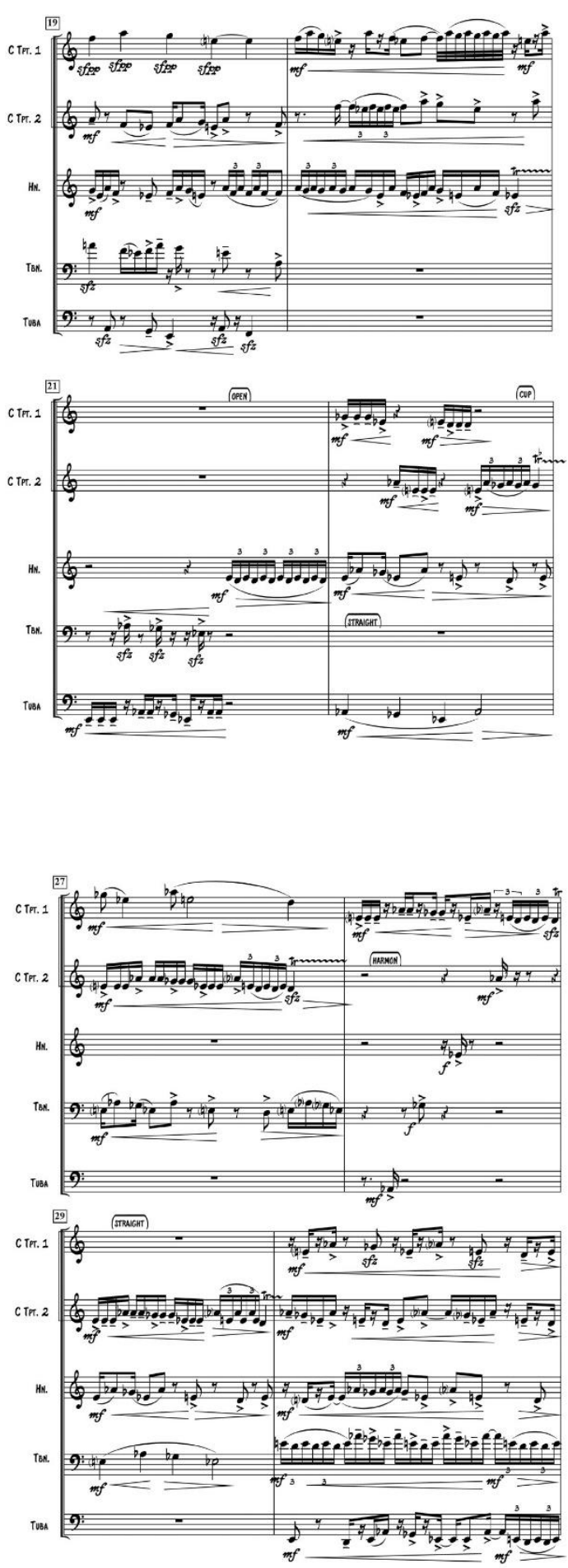

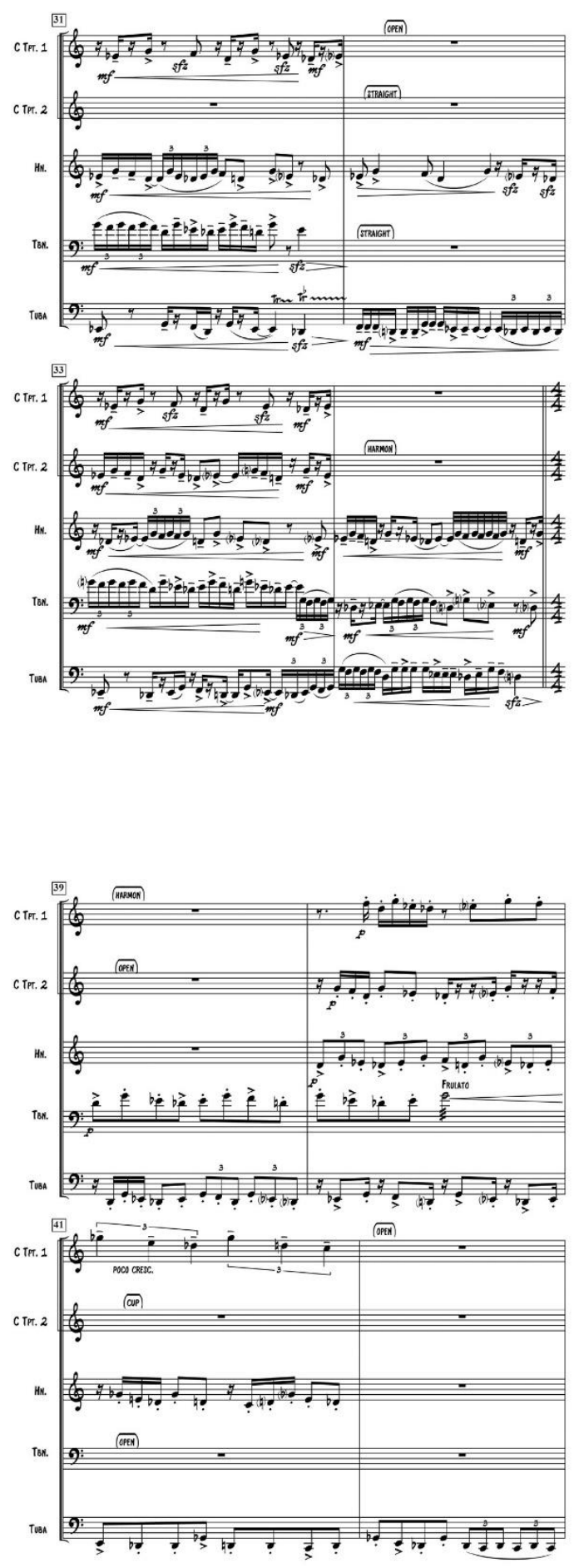
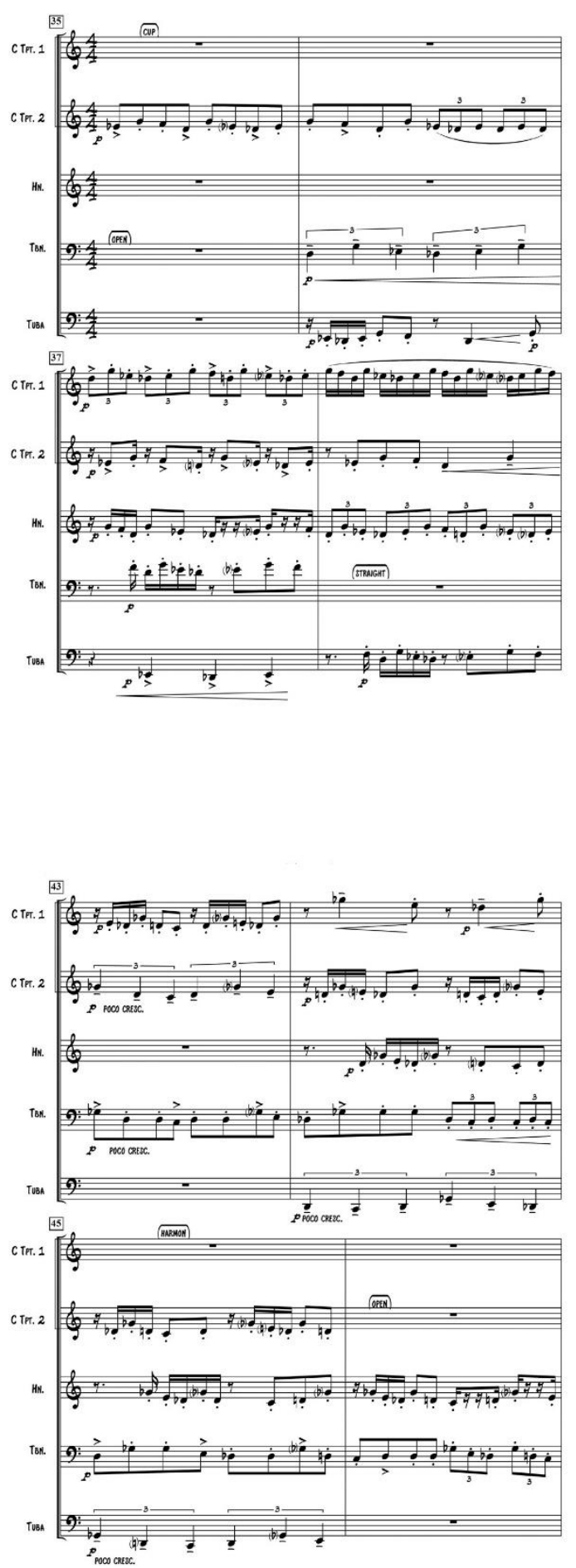

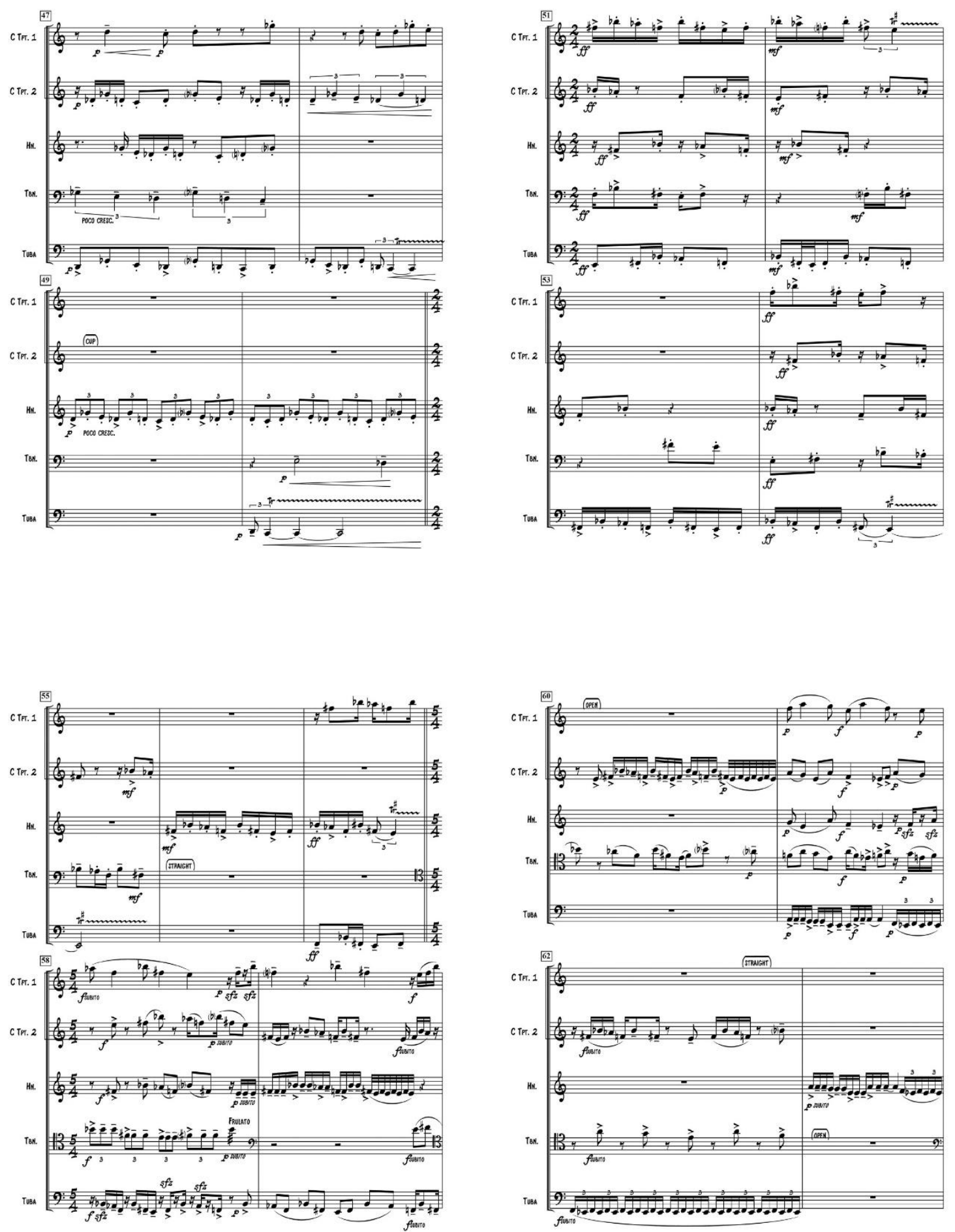

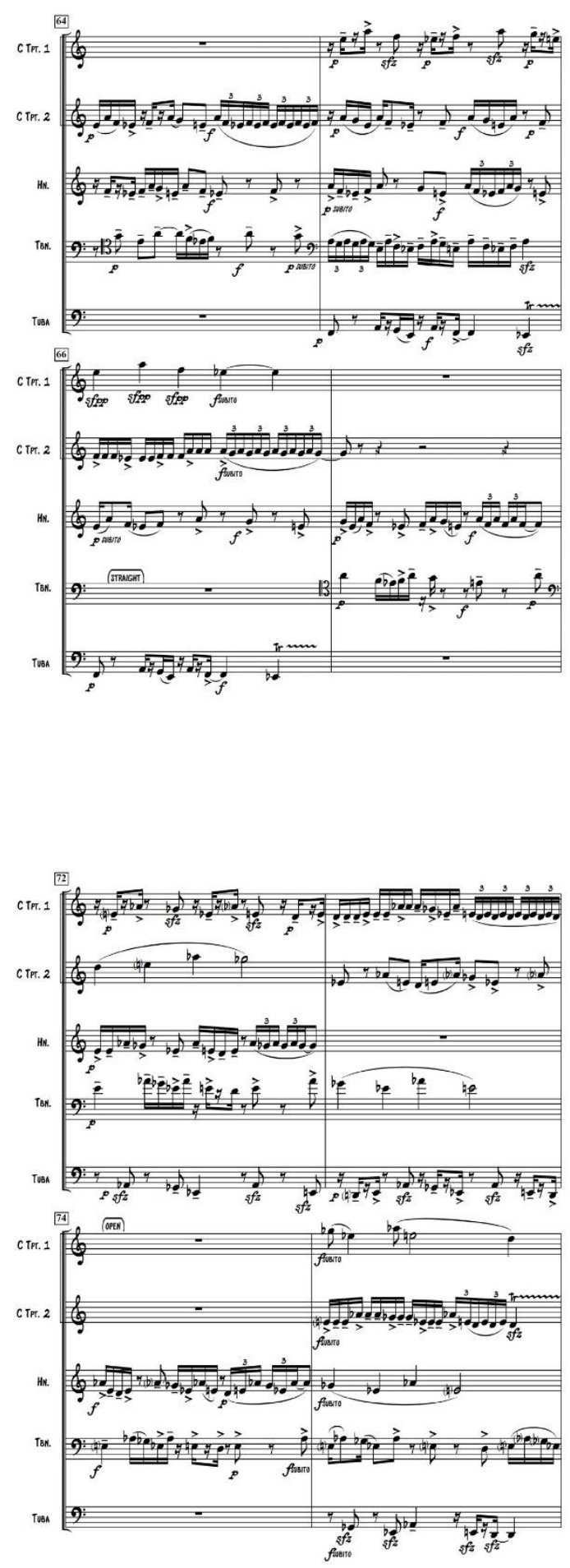
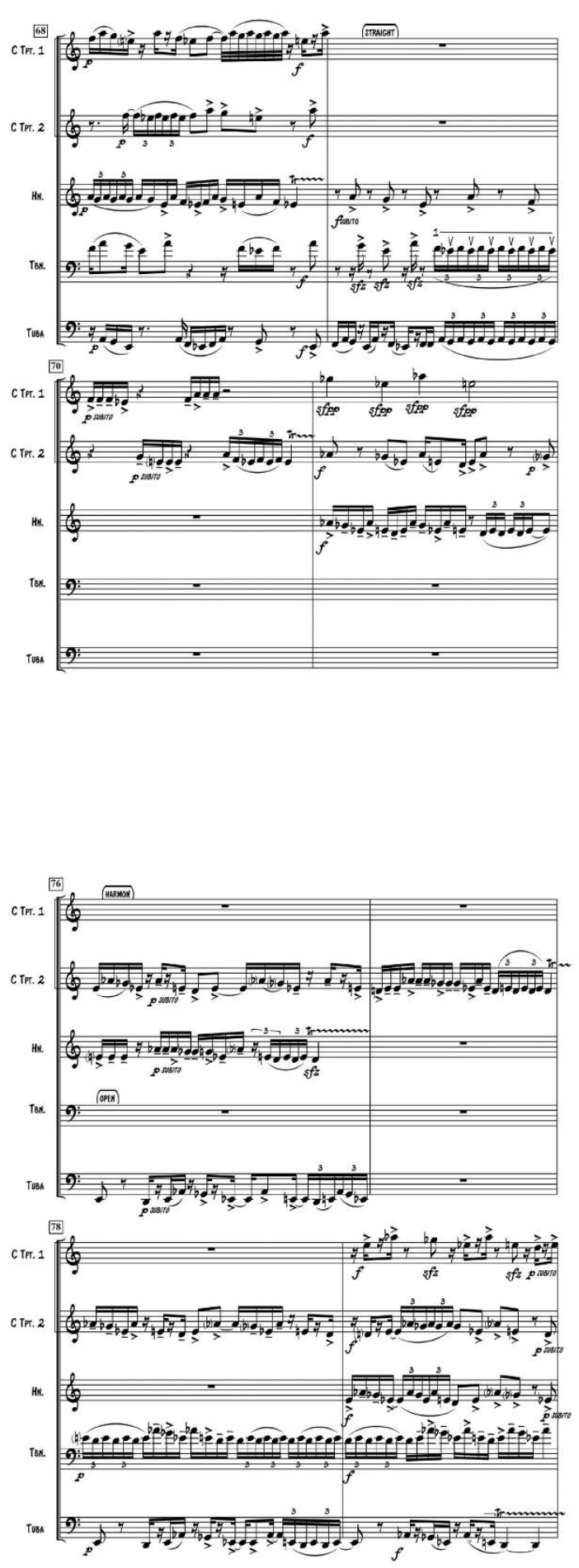

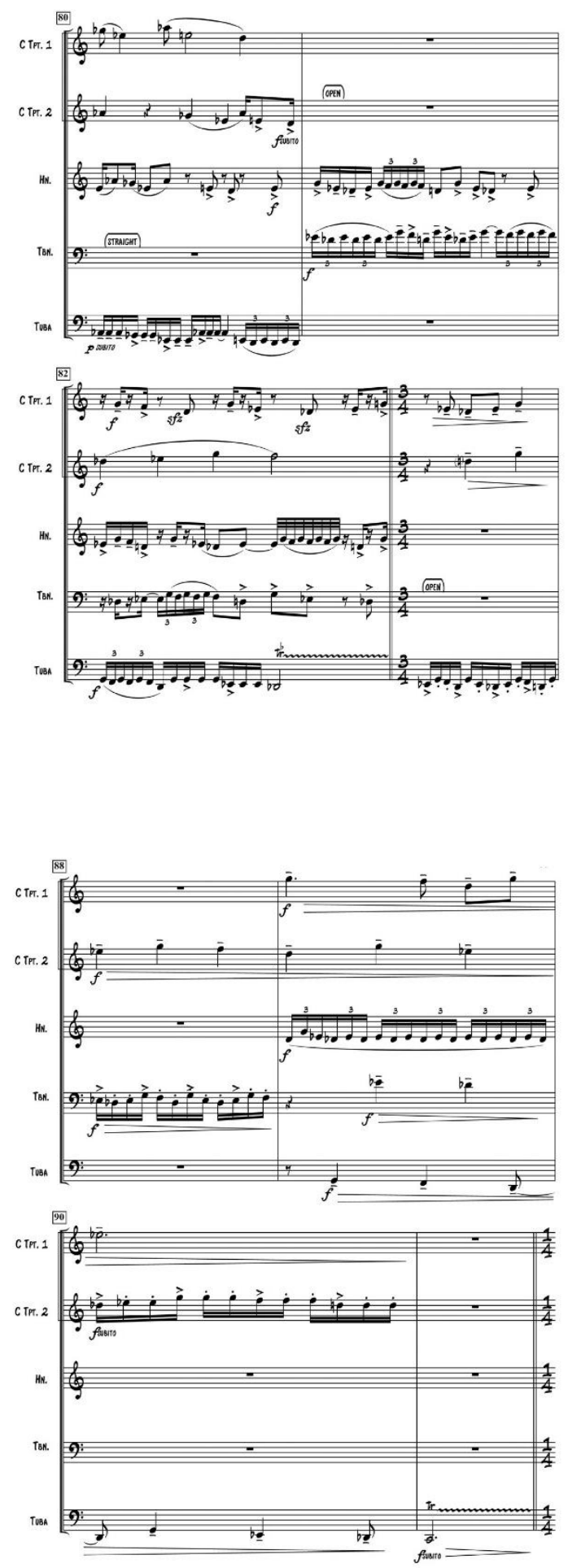
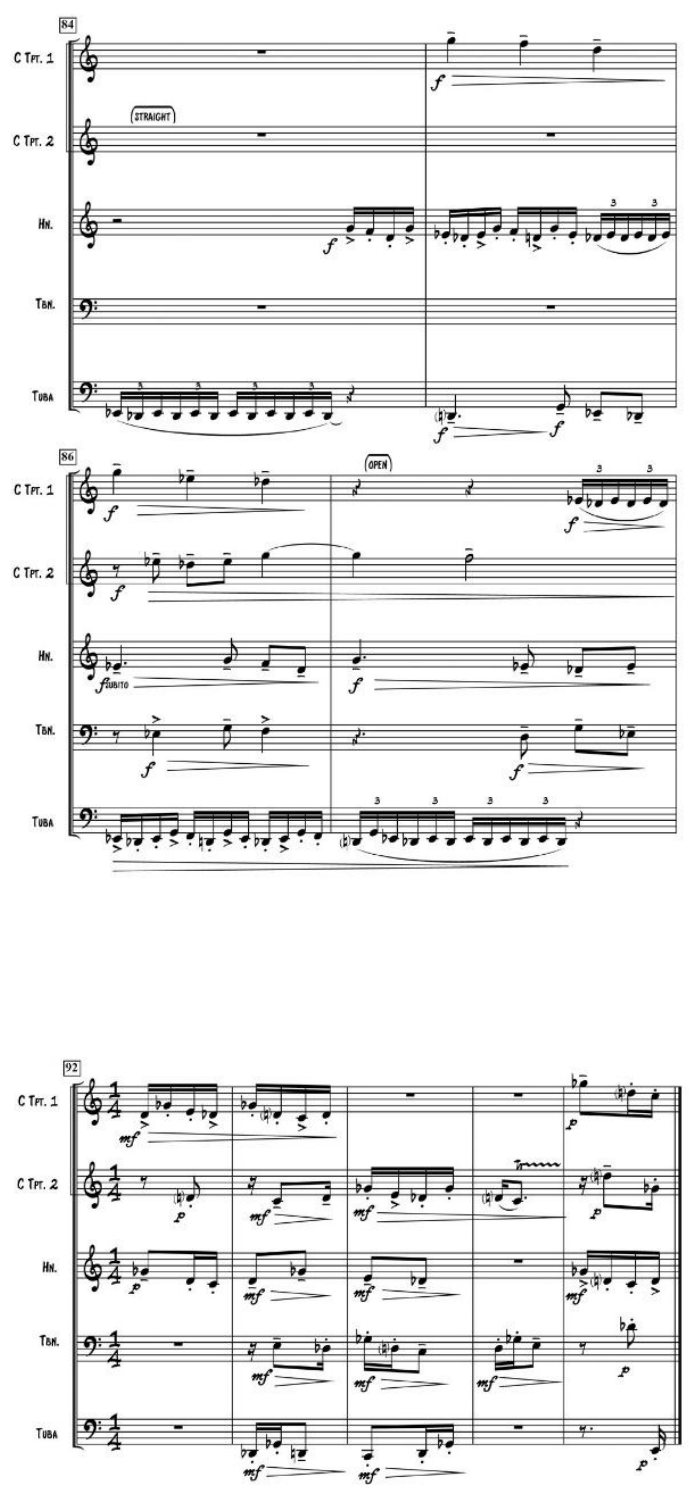